\title{
KUALITAS UDARA DAN POTENSI TRANSMISI COVID-19 DI PULAU JAWA
}

\author{
(Air Quality and the Potency of COVID-19 Transmission in Java) \\ Rizky Zulkarnain ${ }^{1}$, Karuniawati Dewi Ramadani² \\ Badan Pusat Statistik ${ }^{1}$ \\ Badan Pusat Statistik ${ }^{2}$ \\ JI. Dr. Sutomo No. 6-8 Jakarta 10710 \\ E-mail: zulqarnaen@bps.go.id
}

\begin{abstract}
ABSTRAK
Penularan SARS-CoV-2 di Indonesia semakin mengkhawatirkan. Pandemik COVID-19 tidak hanya berdampak pada individu yang terinfeksi langsung, tetapi juga berimbas kepada para penyintas kolateral, yaitu mereka yang kehidupannya ikut terdisrupsi akibat krisis. Pulau Jawa adalah episentrum penularan COVID-19 di Indonesia. Beberapa studi menunjukkan bahwa kejadian COVID-19 memiliki hubungan yang erat dengan tingginya konsentrasi zat partikulat di udara. Penelitian ini bertujuan untuk mengetahui hubungan antara kualitas udara dan risiko penularan COVID-19 di Pulau Jawa. Kualitas udara diukur dengan konsentrasi $\mathrm{NO}_{2}$, sedangkan risiko penularan COVID-19 direfleksikan oleh Indeks Kewaspadaan COVID-19. Penelitian ini menggunakan empat model untuk melihat pengaruh kadar $\mathrm{NO}_{2}$ terhadap Indeks Kewaspadaan COVID-19, dimana variabel kepadatan penduduk ditambahkan sebagai kontrol. Model-0 adalah model dasar tanpa efek kelompok dan efek spasial. Model-1 adalah pengembangan dari Model-0 dengan menambahkan efek spasial. Model-2 adalah pengembangan dari Model-0 dengan menambahkan efek kelompok. Sedangkan, Model-3 adalah model lengkap dengan efek kelompok dan efek spasial. Hasil analisis menunjukkan bahwa Model-3 adalah model terbaik dalam menjelaskan pengaruh kadar $\mathrm{NO}_{2}$ terhadap Indeks Kewaspadaan COVID-19. Model-3 mampu meningkatkan kinerja model secara substansial. Hasil pengujian mengindikasikan bahwa kadar $\mathrm{NO}_{2}$ berpengaruh positif dan signifikan terhadap Indeks Kewaspadaan COVID-19, setelah efek kelompok dan efek spasial diperhitungkan. Dengan demikian, disimpulkan bahwa semakin tinggi konsentrasi $\mathrm{NO}_{2}$ yang mencerminkan semakin buruk kualitas udara, semakin tinggi pula risiko penularan COVID-19. Hasil ini memiliki implikasi penting untuk strategi pencegahan penyebaran COVID-19, khususnya pada daerah-daerah dengan tingkat pencemaran udara yang tinggi.
\end{abstract}

Kata kunci: indeks kewaspadaan, $\mathrm{NO}_{2}$, SARS-CoV-2, Sentinel-5P, spasial

\section{ABSTRACT}

The spreading of SARS-CoV-2 in Indonesia is increasingly worrying. COVID-19 pandemic has disrupted people's lives, not only infected people but also the collateral survivors, that is people who are not infected but suffer disruption in their life due to a crisis. Java island is the epicenter of COVID-19 transmission in Indonesia. Several studies have shown that the incidence of COVID-19 has strong connections with the concentration of particulate matter in air. This study investigates the relationship between air quality and the risk of COVID-19 transmission in Java. Air quality is represented by $\mathrm{NO}_{2}$ concentration, while the risk of COVID19 transmission is measured using COVID-19 Vigilance Index. This paper employs four models to identify the effect of $\mathrm{NO}_{2}$ exposure to the risk of COVID-19 transmission, where the population density is incorporated as control variable. Model- 0 is the base model without cluster and spatial effects. Model-1 is the extension of Model- 0 by adding spatial effect. Model-2 is the extension of Model-O by adding cluster effect. While Model-3 is the complete model with spatial and cluster effects. The results showed that Model-3 is the best model in terms of explaining the relationship between $\mathrm{NO}_{2}$ concentration and the COVID-19 Vigilance Index. Model-3 improves the performance of base model substantially. Furthermore, estimation results suggest that $\mathrm{NO}_{2}$ concentration has positive connections with COVID-19 Vigilance Index, after cluster and spatial effects are considered. Regions with higher $\mathrm{NO}_{2}$ concentration (worse air quality) tend to have higher COVID-19 Vigilance Index (higher risk of COVID-19 transmission). These results have important implications for the mitigation strategies needed to handle COVID-19 transmission, especially in regions that have poor air quality.

Keywords: vigilance index, $\mathrm{NO}_{2}$, SARS-CoV-2, Sentinel-5P, spatial 


\section{PENDAHULUAN}

Pemerintah Indonesia mengumumkan kasus pertama COVID-19 pada tanggal 2 Maret 2020. Sejak saat itu, penyakit yang disebabkan oleh virus SARS-CoV-2 tersebut menyebar secara masif ke berbagai wilayah di Indonesia. Bahkan, perkembangan kasus COVID-19 di Indonesia lebih cepat daripada negara-negara ASEAN lainnya (Gambar 1). Berdasarkan data covid19.go.id, jumlah terkonfirmasi positif COVID-19 di Indonesia sudah mencapai 172.053 kasus per tanggal 31 Agustus 2020. Kondisi tersebut menempatkan Indonesia sebagai salah satu negara dengan kasus COVID-19 tertinggi di ASEAN.

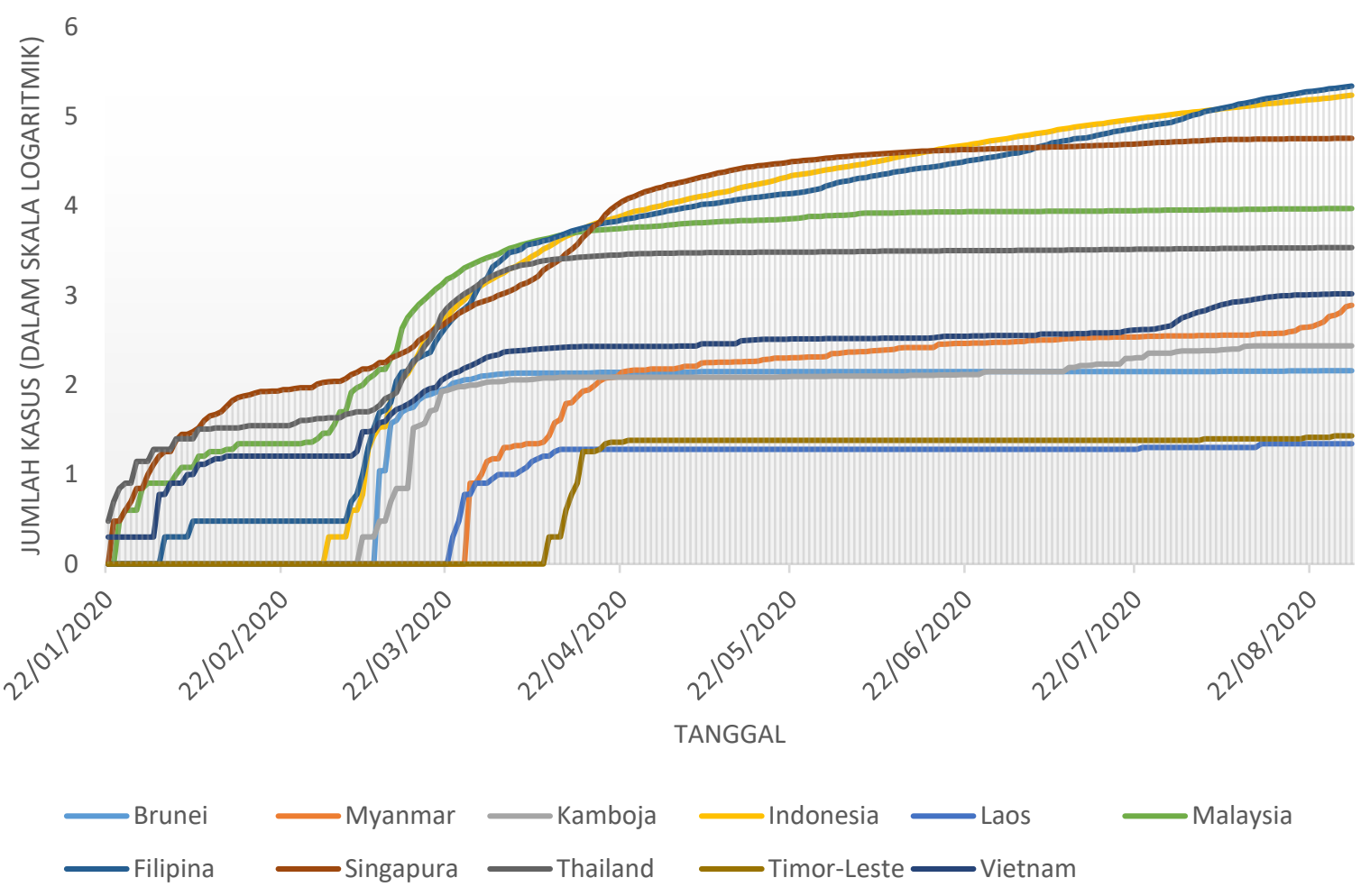

Sumber: data.humdata.org (diolah)

Gambar 1. Perkembangan kasus COVID-19 di ASEAN (dalam skala logaritmik).

Meskipun tingkat kematian akibat COVID-19 lebih rendah daripada Ebola, MERS dan SARS, namun tingkat infeksinya bisa lebih tinggi (ADB, 2020). Tabel 1 menunjukkan bahwa tingkat kematian akibat Ebola, MERS, SARS dan COVID-19 berturut-turut sebesar 50\%, 34,3\%, 10\% dan 1\%-3,4\%. Sementara itu, tingkat infeksinya berturut-turut sebesar 1,5-2,5, 0,42-0,92, 3, dan 1,53,5. Hal ini menunjukkan bahwa COVID-19 memiliki risiko penyebaran yang lebih tinggi dibandingkan penyakit epidemik lainnya. Pandemik COVID-19 tidak hanya berdampak pada individu yang terinfeksi langsung, tetapi juga berimbas kepada para penyintas kolateral, yaitu mereka yang kehidupannya ikut terdisrupsi akibat krisis. Penyintas kolateral dapat berupa mereka yang kehilangan penghasilan akibat krisis maupun mereka yang mengalami trauma akibat ketakutan selama pandemik.

Tabel 1. Tingkat kematian dan tingkat infeksi COVID-19 dan penyakit epidemik lainnya.

\begin{tabular}{lcc}
\hline & Tingkat kematian (kematian/kasus) & Tingkat infeksi (per orang yang terinfeksi) \\
\hline Ebola & $50 \%$ & $1,5-2,5$ \\
MERS & $34,3 \%$ & $0,42-0,92$ \\
SARS & $10 \%$ & 3 \\
COVID-19 & $1 \%-3,4 \%$ & $1,5-3,5$ \\
Flu musiman & $0,05 \%$ & 1,3 \\
\hline
\end{tabular}

Sumber: $A D B, 2020$ 
Pulau Jawa adalah episentrum penularan COVID-19 di Indonesia. Lebih dari separuh kasus COVID-19 di Indonesia berada di Pulau Jawa, yang didominasi oleh empat provinsi utama yaitu DKI Jakarta (22,7\%), Jawa Timur (19,3\%), Jawa Tengah (8,0\%) dan Jawa Barat $(6,3 \%)$. Penularan COVID-19 di Pulau Jawa memiliki dampak besar terhadap kondisi sosial dan ekonomi nasional karena sekitar 56 persen penduduk Indonesia berada di Pulau Jawa dan 59 persen perekonomian nasional dikontribusikan oleh Pulau Jawa (BPS, 2020).

Beberapa studi menunjukkan bahwa kejadian COVID-19 memiliki hubungan yang erat dengan tingginya konsentrasi zat partikulat di udara. Wu et al. (2020) menemukan bahwa paparan jangka panjang terhadap zat partikulat $\left(\mathrm{PM}_{2.5}\right)$ meningkatkan risiko kematian akibat COVID-19 di Amerika Serikat. Peningkatan $\mathrm{PM}_{2.5}$ sebesar $1 \mu \mathrm{g} / \mathrm{m}^{3}$ berdampak pada peningkatan kematian akibat COVID19 sebesar 15\%. Selanjutnya, Andree (2020) menunjukkan bahwa $\mathrm{PM}_{2.5}$ merupakan prediktor penting kasus COVID-19 di Belanda. Jika konsentrasi PM 2.5 meningkat 20\%, maka kasus COVID-19 meningkat hampir $100 \%$. Hasil tersebut robust untuk berbagai spesifikasi model yang mempertimbangkan ketergantungan spasial, nonlinieritas, alternatif distribusi error, dan penanganan pencilan. Hasil tersebut juga konsisten setelah mempertimbangkan berbagai variabel kontrol seperti prakondisi kesehatan dan kondisi demografi. Becchetti et al. (2020) menjelaskan bahwa terdapat dua alasan mengapa polusi udara dapat menjadi faktor penarik COVID-19. Pertama, seseorang yang tinggal di daerah dengan kualitas udara yang buruk cenderung memiliki paru-paru yang bermasalah, sehingga memiliki ketahanan yang lebih rendah terhadap penyakit pernapasan seperti COVID-19. Kedua, zat partikulat dapat menjadi pembawa (carrier) virus bertahan di udara.

Penelitian lain dilakukan oleh Ogen (2020) yang menemukan bahwa sekitar $78 \%$ kasus kematian akibat COVID-19 di Italia, Spanyol, Prancis dan Jerman berada di daerah-daerah dengan konsentrasi nitrogen dioksida $\left(\mathrm{NO}_{2}\right)$ yang tinggi. Kasus tertinggi di Italia terjadi di wilayah Lombardia yang merupakan salah satu wilayah dengan kualitas udara terburuk di Eropa. Bahkan, jauh sebelum itu van Donkelaar et al. (2016) menyatakan bahwa China merupakan salah satu negara dengan kualitas $\mathrm{PM}_{2.5}$ yang buruk dimana Provinsi Hubei adalah salah satu wilayah dengan polusi udara yang tinggi. Seperti yang telah diketahui, Provinsi Hubei adalah daerah awal penyebaran COVID-19. Tingginya jumlah kasus COVID-19 di Pulau Jawa juga mungkin berasosiasi dengan kualitas udara yang buruk. Gambar 2 menunjukkan bahwa terdapat beberapa hotspot $\mathrm{NO}_{2}$ di Pulau Jawa, yaitu di sekitar wilayah Jabodetabek dan beberapa wilayah di Provinsi Jawa Timur. Gambar 3 menunjukkan bahwa daerah-daerah tersebut juga memiliki kasus COVID-19 yang tinggi. Penelitian ini bertujuan untuk mengetahui hubungan antara kualitas udara dan risiko penularan COVID-19 di Pulau Jawa. Penelitian ini memanfaatkan beberapa teknik regresi untuk menjelaskan bagaimana kualitas udara berdampak pada risiko penularan COVID-19 di Pulau Jawa.

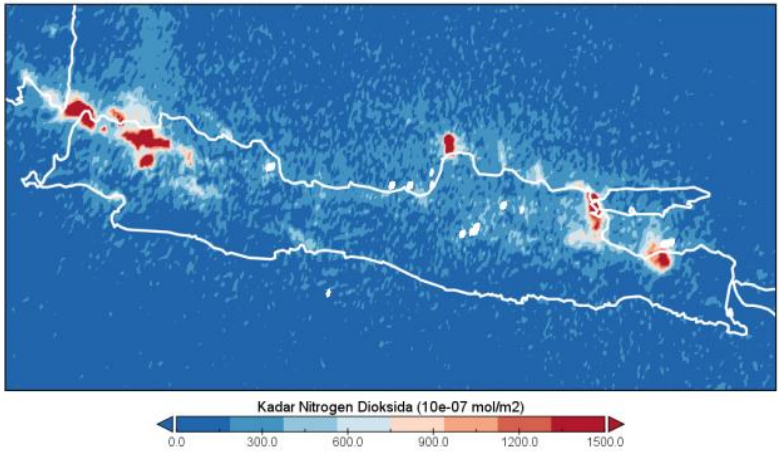

Gambar 2. Heatmap $\mathrm{NO}_{2}$ di Pulau Jawa berdasarkan citra satelit Sentinel-5P.

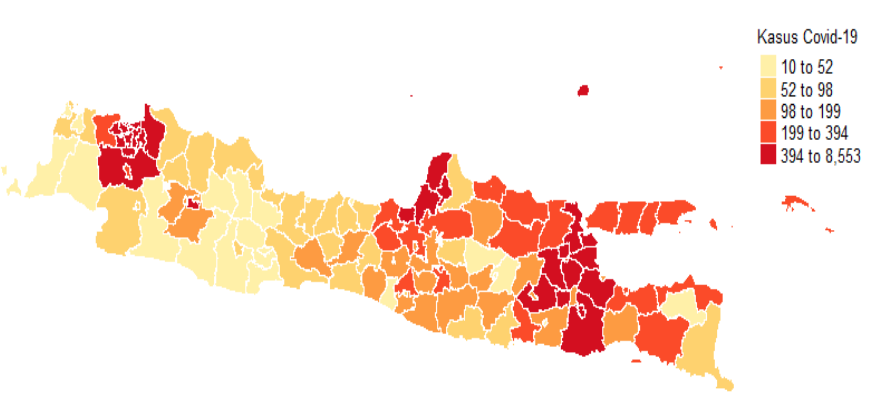

Gambar 3. Distribusi spasial kasus COVID-19 di Pulau Jawa (per tanggal 29 Juli 2020).

\section{METODE}

\section{Data}

Kualitas udara dalam penelitian ini direpresentasikan oleh konsentrasi nitrogen dioksida $\left(\mathrm{NO}_{2}\right)$, sedangkan risiko penularan COVID-19 diukur menggunakan Indeks Kewaspadaan COVID-19. Data konsentrasi $\mathrm{NO}_{2}$ diperoleh dari citra satelit Sentinel-5P, sedangkan Indeks Kewaspadaan COVID-19 
diperoleh dari situs kawalcovid19.id. Penelitian ini juga menggunakan data kepadatan penduduk sebagai variabel kontrol. Data kepadatan penduduk diperoleh dari Badan Pusat Statistik (BPS). Unit analisis yang digunakan dalam penelitian ini adalah 119 kabupaten/kota di Pulau Jawa.

Sentinel-5 Precursor (Sentinel-5P) merupakan satelit sentinel Eropa pertama yang didedikasikan untuk mengamati komposisi atmosfer, yang merupakan hasil kerjasama antara European Space Agency (ESA), European Commission dan Netherlands Space Office (Eskes et al., 2019). Sentinel5P diluncurkan pertama kali pada tanggal 13 Oktober 2017 sebagai bagian dari program Copernicus untuk memantau kualitas udara, iklim dan lapisan ozon secara global. Enam bulan pertama peluncuran Sentinel-5P merupakan fase observasi khusus untuk mempersiapkan satelit dan sistem pemrosesan permukaan bumi, sehingga fase operasional Sentinel-5P baru dimulai pada bulan April 2018. Sentinel-5P beroperasi pada orbit dengan ketinggian $824 \mathrm{~km}$ dengan siklus orbit selama 16 hari. Sentinel-5P direncanakan beroperasi hingga tahun 2023.

Sentinel-5P memuat spektrometer yang disebut Tropospheric Monitoring Instrument (TROPOMI). TROPOMI berguna untuk mengukur panjang gelombang $U V$-visible $(270-500 \mathrm{~nm})$, near infrared $(710-770 \mathrm{~nm})$ dan shortwave infrared $(2314-2382 \mathrm{~nm})$. TROPOMI memiliki resolusi spasial sebesar 7 × 3,5 km² untuk band 2-6 (UVN), 7 × $7 \mathrm{~km}^{2}$ untuk band 7 dan 8 (SWIR), dan $21 \times 28 \mathrm{~km}^{2}$ untuk band 1 (deep UV). Dengan resolusi tersebut, TROPOMI memiliki keunggulan dibandingkan pendahulunya seperti OMI (Ozone Monitoring Instrument), SCIAMACHY (Scanning Imaging Absorption Spectrometer for Atmospheric Chartography) dan GOME-2 (Global Ozone Monitoring Experiment-2). Data kadar $\mathrm{NO}_{2}$ dalam penelitian ini merupakan rata-rata konsentrasi $\mathrm{NO}_{2}$ dari bulan Januari hingga Juli 2020. Hal ini dimaksudkan untuk menangkap paparan jangka panjang $\mathrm{NO}_{2}$ di suatu wilayah. Data kadar $\mathrm{NO}_{2}$ juga dirata-ratakan menurut kabupaten/kota untuk mendapatkan angka level kabupaten/kota. Untuk keperluan pemodelan, data kadar $\mathrm{NO}_{2}$ dikonversi dari $\mathrm{mol} / \mathrm{m}^{2} \mathrm{ke}$ molekul $/ \mathrm{cm}^{2}$ menggunakan faktor pengali sebesar 6,02214 x $10^{19}$.

Data Indeks Kewaspadaan COVID-19 yang digunakan dalam penelitian ini adalah kondisi per tanggal 29 Juli 2020. Indeks tersebut tersedia menurut level kabupaten/kota. Indeks Kewaspadaan COVID-19 merupakan ukuran yang lebih komprehensif karena tidak hanya didasarkan pada jumlah kasus terkonfirmasi, namun juga mempertimbangkan jumlah kasus suspek, jumlah kasus kontak erat, jumlah yang meninggal, jumlah yang sembuh dan rasio testing. Dengan demikian, Indeks Kewaspadaan COVID-19 memperhitungkan adanya potensi transmisi di komunitas yang tidak terdeteksi oleh jumlah kasus terkonfirmasi. Kenaikan jumlah kasus positif COVID-19, kasus suspek dan banyaknya yang meninggal akan meningkatkan Indeks Kewaspadaan COVID-19, sedangkan kenaikan jumlah yang sembuh, rasio testing dan kasus kontak erat akan menurunkan Indeks Kewaspadaan COVID-19. Data-data tersebut dinormalisasi terhadap luas daerah dan jumlah penduduk. Skor Indeks Kewaspadaan COVID-19 memiliki rentang dari 0 sampai dengan 20. Semakin tinggi skor Indeks Kewaspadaan COVID-19, semakin tinggi kemungkinan terjadi transmisi komunitas di suatu wilayah (kawalcovid19.id).

\section{Model}

Penelitian ini membandingkan empat model dalam menjelaskan pengaruh kadar $\mathrm{NO}_{2}$ terhadap Indeks Kewaspadaan COVID-19. Variabel kepadatan penduduk ditambahkan pada masing-masing model sebagai variabel kontrol. Model-0 adalah model dasar tanpa efek kelompok dan efek spasial. Model-1 adalah pengembangan dari Model-0 dengan menambahkan efek spasial. Penyakit epidemik seperti COVID-19 biasanya mudah menular pada daerah-daerah yang berdekatan, sehingga memiliki ketergantungan spasial yang kuat. Selanjutnya, Model-2 adalah pengembangan dari Model-0 dengan menambahkan efek kelompok. Efek kelompok ditambahkan dalam studi ini untuk menangkap kemiripan pola antar daerah yang tidak disebabkan oleh kedekatan jarak geografis, misalnya karena kemiripan struktur demografi. Terakhir, Model-3 adalah model lengkap dengan efek kelompok dan efek spasial. Spesifikasi dari masing-masing model adalah sebagai berikut:

- Model-0: model tanpa efek kelompok dan efek spasial

$$
y_{i}=\beta_{0}+\beta_{1} x_{1 i}+\beta_{2} x_{2 i}+\varepsilon_{i}
$$

- Model-1: model dengan efek spasial

$$
y_{i}=\beta_{0}+\beta_{1} x_{1 i}+\beta_{2} x_{2 i}+\rho \sum_{j=1}^{n} w_{i j} y_{j}+u_{i}
$$




$$
\text { dengan } u_{i}=\lambda \sum_{j=1}^{n} w_{i j} u_{j}+\varepsilon_{i}
$$

- Model-2: model dengan efek kelompok

$$
y_{i}=\beta_{0}+\beta_{1} x_{1 i}+\beta_{2} x_{2 i}+\sum_{d=1}^{K-1} \delta_{d} D_{d}+\sum_{d=1}^{K-1} \tau_{d} D_{d} x_{1 i}+\varepsilon_{i}
$$

- Model-3: model dengan efek kelompok dan efek spasial

$$
\begin{aligned}
& y_{i}=\beta_{0}+\beta_{1} x_{1 i}+\beta_{2} x_{2 i}+\sum_{d=1}^{K-1} \delta_{d} D_{d}+\sum_{d=1}^{K-1} \tau_{d} D_{d} x_{1 i}+\rho \sum_{j=1}^{n} w_{i j} y_{j}+u_{i} \\
& \text { dengan } u_{i}=\lambda \sum_{j=1}^{n} w_{i j} u_{j}+\varepsilon_{i}
\end{aligned}
$$

dimana:

$y_{i}=$ Indeks Kewaspadaan COVID-19 pada kabupaten/kota ke-i

$x_{1 i}=$ kadar nitrogen dioksida $\left(\mathrm{NO}_{2}\right)$ pada kabupaten/kota ke-i

$x_{2 i}=$ kepadatan penduduk pada kabupaten/kota ke-i

$D_{d}=$ dummy kelompok ke-d, $d=1,2, \ldots, K-1$

$D_{d}= \begin{cases}1, & \text { jika kelompok ke-d } \\ 0, & \text { jika kelompok lainnya }\end{cases}$

$w_{i j}=$ bobot spasial antara kabupaten ke-i dan kabupaten ke-j

$\beta_{0}=$ konstanta

$\beta_{1}=$ koefisien untuk variabel kadar nitrogen dioksida $\left(\mathrm{NO}_{2}\right)$

$\beta_{2}=$ koefisien untuk variabel kepadatan penduduk

$\delta_{d}=$ koefisien yang mencerminkan perbedaan intercept antara kelompok ke-d dengan kelompok referensi

$\tau_{d}=$ koefisien yang mencerminkan perbedaan slope/pengaruh $\mathrm{NO}_{2}$ antara kelompok ke-d dengan kelompok referensi

$\rho=$ koefisien spatial autoregressive, $|\rho|<1$

$\lambda=$ koefisien spatial autocorrelation, $|\lambda|<1$

$\varepsilon_{i}=$ error pengamatan ke-i, $\varepsilon_{i} \sim N\left(0, \sigma^{2}\right)$

$K=$ banyaknya kelompok

$n=$ banyaknya kabupaten/kota

Model pada persamaan (1) dan (3) pada dasarnya merupakan model regresi linier standar, sehingga parameternya dapat diduga menggunakan metode kuadrat terkecil (Darlington \& Hayes, 2017). Sedangkan, model pada persamaan (2) dan (4) disebut sebagai model spatial autoregressive combined (SAC) yang parameternya diduga menggunakan metode maximum likelihood. Berdasarkan taksonomi Elhorst (2014), jika $\rho \neq 0$ dan $\lambda=0$, maka model SAC akan berubah menjadi model spatial lag (SAR). Sedangkan, jika $\lambda \neq 0$ dan $\rho=0$, maka model SAC akan berubah menjadi model spatial error (SEM). Pemilihan antara model SAR, SEM dan SAC dilakukan dengan menggunakan uji Lagrange Multiplier(LM) sebagai berikut (Anselin et al., 1996):

- Uji LM untuk SAR:

Ho: $\rho=0$ (tidak ada ketergantungan spasial pada variabel dependen)

$\mathrm{H}_{1}: \rho \neq 0$ (ada ketergantungan spasial pada variabel dependen)

Statistik uji:

$$
L M_{S A R}=\frac{\left(\frac{\boldsymbol{e}^{\prime} \boldsymbol{W} \boldsymbol{y}}{\hat{\sigma}_{M L}^{2}}\right)^{2}}{\frac{(\boldsymbol{W} \boldsymbol{X} \widehat{\boldsymbol{\beta}})^{\prime}\left(\boldsymbol{I}-\boldsymbol{X}\left(\boldsymbol{X}^{\prime} \boldsymbol{X}\right)^{-1} \boldsymbol{X}^{\prime}\right) \boldsymbol{W} \boldsymbol{X} \widehat{\boldsymbol{\beta}}}{\hat{\sigma}_{M L}^{2}}+\operatorname{tr}\left[\boldsymbol{W}^{2}+\boldsymbol{W}^{\prime} \boldsymbol{W}\right]}
$$

Ho ditolak jika $L M_{S A R}>\chi_{(1), \alpha}^{2}$

- Uji LM untuk SEM:

Ho: $\lambda=0$ (tidak ada ketergantungan spasial pada error)

$\mathrm{H}_{1}: \lambda \neq 0$ (ada ketergantungan spasial pada error) 
Statistik uji:

$$
L M_{S E M}=\frac{\left(\frac{\boldsymbol{e}^{\prime} \boldsymbol{W} \boldsymbol{e}}{\hat{\sigma}_{M L}^{2}}\right)^{2}}{\operatorname{tr}\left[\boldsymbol{W}^{2}+\boldsymbol{W}^{\prime} \boldsymbol{W}\right]}
$$

Ho ditolak jika $L M_{S E M}>\chi_{(1), \alpha}^{2}$

- Uji LM untuk SAC:

Ho: $\rho=0$ dan $\lambda=0$ (tidak ada ketergantungan spasial)

$\mathrm{H}_{1}: \rho \neq 0$ dan $\lambda \neq 0$ (ada ketergantungan spasial)

Statistik uji:

$$
L M_{S A C}=\frac{\left(\frac{\boldsymbol{e}^{\prime} \boldsymbol{W} \boldsymbol{y}}{\hat{\sigma}_{M L}^{2}}-\frac{\boldsymbol{e}^{\prime} \boldsymbol{W} \boldsymbol{e}}{\hat{\sigma}_{M L}^{2}}\right)^{2}}{\frac{(\boldsymbol{W} \boldsymbol{X} \widehat{\boldsymbol{\beta}})^{\prime}\left(\boldsymbol{I}-\boldsymbol{X}\left(\boldsymbol{X}^{\prime} \boldsymbol{X}\right)^{-1} \boldsymbol{X}^{\prime}\right) \boldsymbol{W} \boldsymbol{X} \widehat{\boldsymbol{\beta}}}{\hat{\sigma}_{M L}^{2}}}+\frac{\left(\frac{\boldsymbol{e}^{\prime} \boldsymbol{W} \boldsymbol{e}}{\hat{\sigma}_{M L}^{2}}\right)^{2}}{\operatorname{tr}\left[\boldsymbol{W}^{2}+\boldsymbol{W}^{\prime} \boldsymbol{W}\right]}
$$

Ho ditolak jika $L M_{S A C}>\chi_{(2), \alpha}^{2}$

Efek spasial tidak hanya berupa ketergantungan spasial (spatial dependency), tetapi juga dapat berupa keragaman spasial (spatial heterogeneity). Untuk mengetahui apakah data yang digunakan mengandung keragaman spasial, maka dilakukan uji Breusch-Pagan sebagai berikut (Arbia, 2006):

Ho: tidak terdapat keragaman spasial

$\mathrm{H}_{1}$ : terdapat keragaman spasial

Statistik uji: $B P=\left(\frac{1}{2}\right)\left(\sum_{i=1}^{n} x_{i}\left(\frac{e_{i}}{\hat{\sigma}}-1\right)\right)^{\prime}\left(\sum_{i=1}^{n} x_{i} x_{i}^{\prime}\right)\left(\sum_{i=1}^{n} x_{i}\left(\frac{e_{i}}{\hat{\sigma}}-1\right)\right)$

Ho ditolak jika $B P>\chi_{(P), \alpha}^{2}$ dimana $P$ adalah banyaknya variabel penjelas

Intensitas hubungan antara unit-unit spasial diukur melalui bobot spasial. Penelitian ini menggunakan metode $k$-nearest neighbors (k-NN) untuk menghitung bobot spasial. Misalkan jarak dari setiap daerah $i$ ke seluruh daerah $j \neq i$ dapat diurutkan menjadi $d_{i j(1)} \leq d_{i j(2)} \leq \cdots \leq d_{i j(n-1)}$. Selanjutnya, untuk setiap $k=1,2, \ldots, n-1, N_{k}(i)=\{j(1), j(2), \ldots, j(k)\}$ adalah himpunan yang memuat $k$ daerah yang paling dekat dengan daerah $i$, maka bobot $\mathrm{k}-\mathrm{NN}$ dapat dihitung sebagai berikut:

$$
w_{i j}= \begin{cases}1, & \text { jika } j \in N_{k}(i) \\ 0, & \text { lainnya }\end{cases}
$$

Bobot spasial yang telah dihitung menggunakan formula (9) selanjutnya dinormalisasi baris sebagai $w_{i j}^{S}=w_{i j} / \sum_{j} w_{i j}$. Hal ini untuk memastikan bahwa jumlah bobot dalam satu baris sama dengan 1.

Koefisien variabel penjelas pada model spasial tidak dapat diinterpretasikan seperti halnya regresi standar. Hal ini disebabkan oleh adanya efek limpahan (spillover), sehingga perubahan variabel penjelas pada suatu daerah tidak hanya berdampak pada variabel dependen di daerah itu sendiri tapi juga berdampak pada variabel dependen di daerah sekitarnya. Interpretasi koefisien pada model spasial dapat dilakukan menggunakan dampak langsung, dampak tak langsung dan dampak total. Formulasi dampak langsung, dampak tak langsung dan dampak total adalah sebagai berikut (LeSage, 2008):

$$
\begin{aligned}
& \boldsymbol{B}_{p}^{-1}=\left(\boldsymbol{I}_{n}-\rho \boldsymbol{W}\right)^{-1} \hat{\beta}_{p}=\left[\begin{array}{cccc}
b_{11}^{p} & b_{12}^{p} & \ldots & b_{1 n}^{p} \\
b_{21}^{p} & b_{22}^{p} & \ldots & b_{2 n}^{p} \\
\vdots & \vdots & \ddots & \vdots \\
b_{n 1}^{p} & b_{n 2}^{p} & \ldots & b_{n n}^{p}
\end{array}\right] \\
& \hat{\beta}_{p}^{T o t}=\frac{1}{n} \sum_{i=1}^{n} \sum_{j=1}^{n} b_{i j}^{p} \\
& \hat{\beta}_{p}^{\text {Dir }}=\frac{1}{n} \sum_{j=1}^{n} b_{j j}^{p} \\
& \hat{\beta}_{p}^{\text {Ind }}=\hat{\beta}_{p}^{\text {Tot }}-\hat{\beta}_{p}^{\text {Dir }}
\end{aligned}
$$


dimana:

$\hat{\beta}_{p}=$ koefisien variabel penjelas ke-p

$\rho=$ koefisien spatial autoregressive, $|\rho|<1$

$\boldsymbol{W}=$ matriks pembobot spasial

$\hat{\beta}_{p}^{T o t}=$ dampak total dari variabel penjelas ke-p

$\hat{\beta}_{p}^{\text {Dir }}=$ dampak langsung dari variabel penjelas ke- $p$

$\hat{\beta}_{p}^{\text {Ind }}=$ dampak tak langsung dari variabel penjelas ke-p

\section{HASIL DAN PEMBAHASAN}

Gambar 4 menyajikan perkembangan kadar $\mathrm{NO}_{2}$ di Pulau Jawa selama bulan Februari 2020 hingga Juli 2020. Pada gambar tersebut terlihat bahwa kadar $\mathrm{NO}_{2}$ di Pulau Jawa cenderung berkurang selama bulan Maret hingga Mei 2020. Hal ini kemungkinan disebabkan oleh berkurangnya aktivitas transportasi dan industri akibat kebijakan Work from Home (WFH) dan Pembatasan Sosial Berskala Besar (PSBB). Namun, sejak bulan Juni 2020 kadar $\mathrm{NO}_{2}$ kembali mengalami peningkatan seiring dengan pelonggaran PSBB. Terdapat beberapa hotspot $\mathrm{NO}_{2}$ di Pulau Jawa, yaitu di sekitar wilayah Jabodetabek, Kota Cilegon dan sebagian wilayah Jawa Timur seperti Kota Surabaya, Kabupaten Gresik dan Kabupaten Probolinggo. Wilayah Jabodetabek, Kota Surabaya dan Kabupaten Gresik merupakan daerah dengan mobilitas penduduk dan kegiatan industri yang tinggi. Sementara itu, di Kota Cilegon dan Kabupaten Probolinggo terdapat Pembangkit Listrik Tenaga Uap (PLTU), yaitu PLTU Suralaya dan PLTU Paiton.
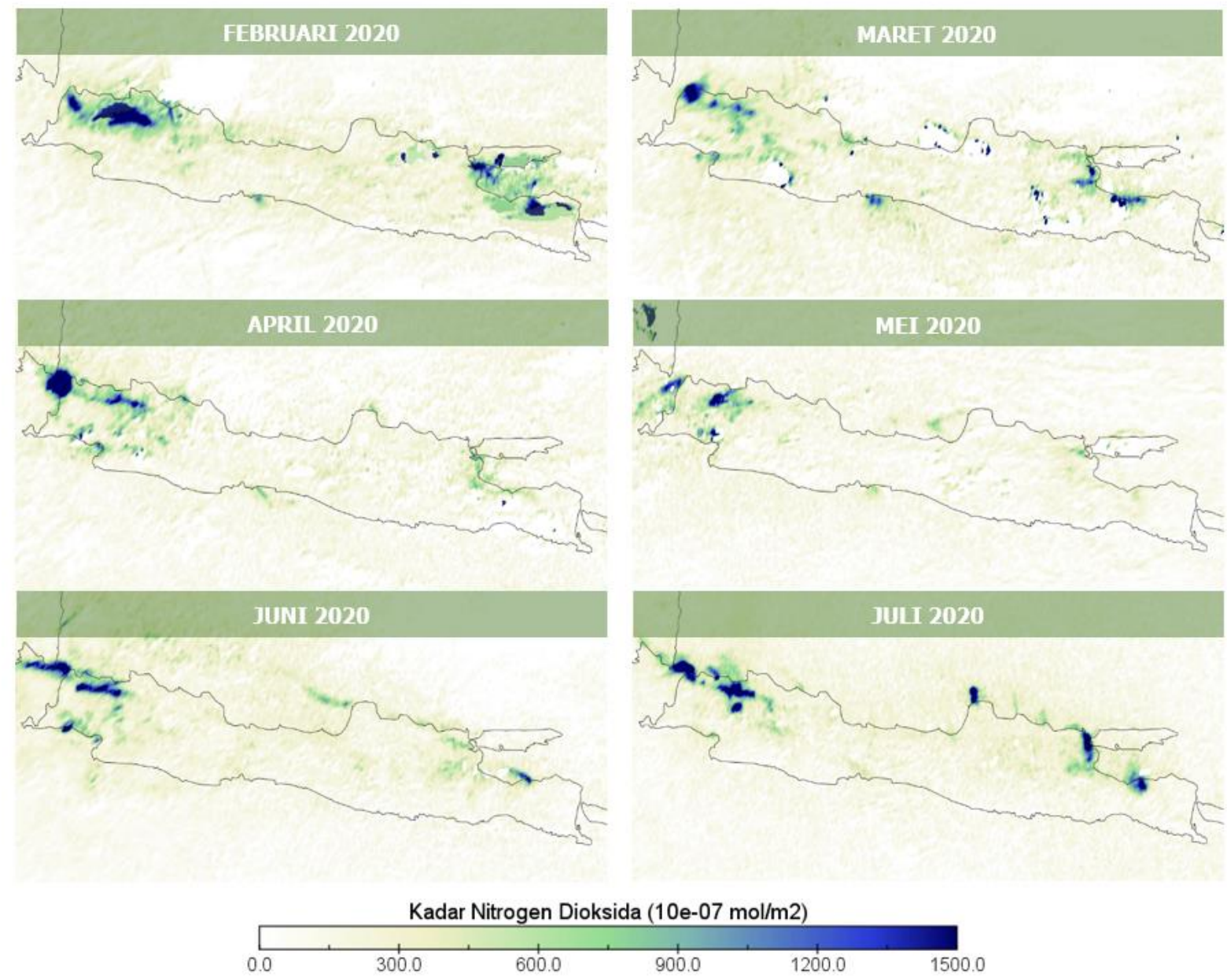

Gambar 4. Perkembangan kadar $\mathrm{NO}_{2}$ di Pulau Jawa (Februari-Juli 2020).

Hubungan antara kadar rata-rata $\mathrm{NO}_{2}$ di setiap kabupaten/kota dan Indeks Kewaspadaan COVID-19 disajikan dalam Gambar 5. Gambar tersebut memperlihatkan pola yang cukup menarik. Hubungan antara kadar $\mathrm{NO}_{2}$ dan Indeks Kewaspadaan COVID-19 tidak berlaku umum, namun 
terbagi menjadi dua kelompok. Pada kelompok pertama (merah), peningkatan kadar $\mathrm{NO}_{2}$ diasosiasikan dengan peningkatan Indeks Kewaspadaan COVID-19 yang relatif moderat. Sedangkan pada kelompok 2 (hijau), peningkatan kadar $\mathrm{NO}_{2}$ berdampak pada peningkatan Indeks Kewaspadaan COVID-19 yang lebih tinggi. Peningkatan kadar $\mathrm{NO}_{2}$ juga berasosiasi dengan peningkatan jumlah kasus positif COVID-19, yang ditunjukkan oleh ukuran titik yang semakin besar pada masing-masing kelompok. Daftar anggota untuk masing-masing kelompok disajikan dalam Tabel 2. Dari Tabel 2 juga diketahui bahwa rata-rata persentase lanjut usia (60 tahun ke atas) pada kelompok 2 lebih tinggi daripada kelompok 1 . Hal ini mungkin menjadi salah satu alasan mengapa kelompok 2 menjadi lebih berisiko daripada kelompok 1 jika terjadi peningkatan kadar $\mathrm{NO}_{2}$ dengan tingkat yang sama.

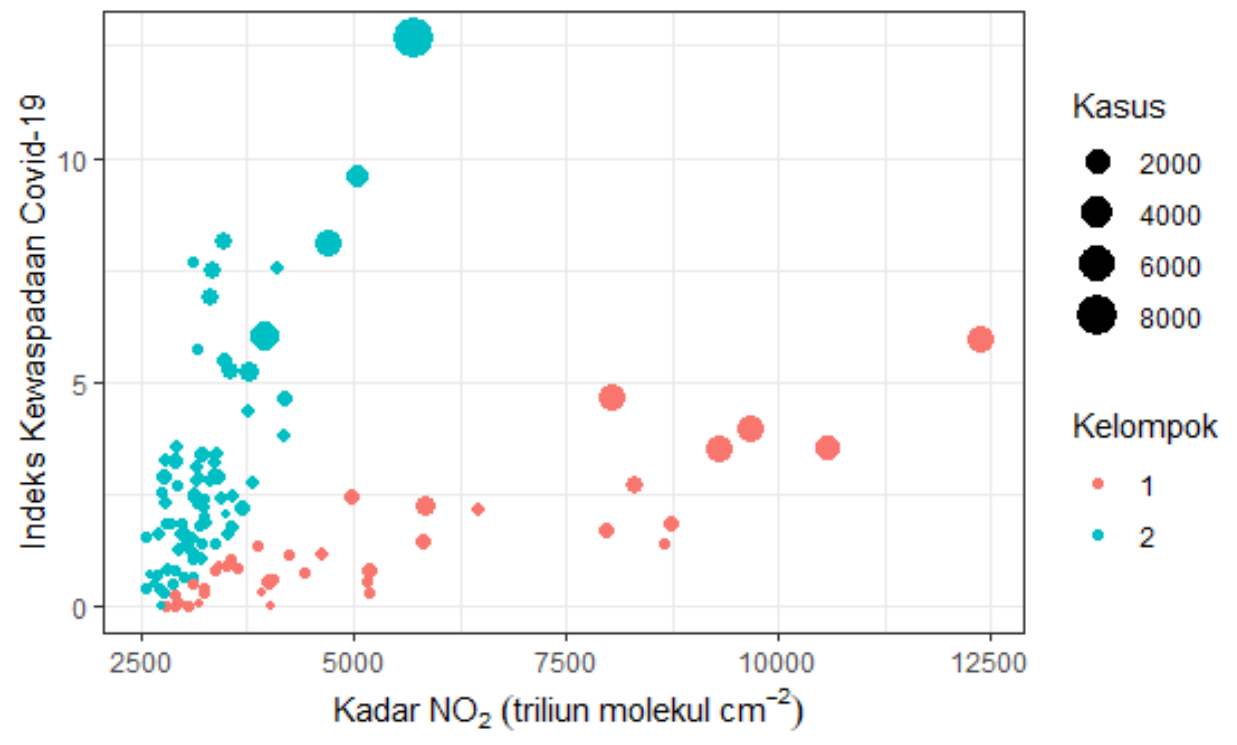

Gambar 5. Bubbleplot kadar $\mathrm{NO}_{2}$ dan Indeks Kewaspadaan COVID-19.

Tabel 2. Daftar anggota untuk masing-masing kelompok.

\begin{tabular}{|c|c|c|c|}
\hline Kelompok & $\begin{array}{l}\text { Jumlah } \\
\text { anggota }\end{array}$ & Daftar kabupaten/kota & $\begin{array}{c}\text { Rata-rata } \\
\text { Persentase } \\
\text { Lansia }\end{array}$ \\
\hline 1 & 41 & $\begin{array}{l}\text { Kota Cilegon, Kota Serang, Kota Tangerang, Kab. Lebak, Kab. Pandeglang, Kab. } \\
\text { Serang, Kab. Tangerang, Kota Tangerang Selatan, Kota Jakarta Barat, Kota Jakarta } \\
\text { Pusat, Kota Jakarta Selatan, Kota Jakarta Timur, Kota Jakarta Utara, Kab. Bandung } \\
\text { Barat, Kota Banjar, Kab. Bekasi, Kab. Bogor, Kab. Ciamis, Kota Cimahi, Kota Depok, } \\
\text { Kab. Garut, Kab. Indramayu, Kab. Karawang, Kota Bandung, Kota Bekasi, Kota } \\
\text { Bogor, Kota Tasikmalaya, Kab. Majalengka, Kab. Purwakarta, Kab. Sukabumi, } \\
\text { Kab.Sumedang, Kab. Brebes, Kab. Cilacap, Kota Pekalongan, Kota Tegal, Kab. Pati, } \\
\text { Kab. Purbalingga, Kab. Tegal, Kab. Madiun, Kab. Ngawi, Kab. Probolinggo }\end{array}$ & $9,26 \%$ \\
\hline 2 & 78 & $\begin{array}{l}\text { Kab. Kepulauan Seribu, Kab. Bandung, Kab. Cianjur, Kab. Cirebon, Kota Cirebon, } \\
\text { Kota Sukabumi, Kab. Kuningan, Kab. Subang, Kab. Tasikmalaya, Kab. Pangandaran, } \\
\text { Kab. Banjarnegara, Kab. Banyumas, Kab. Batang, Kab. Blora, Kab. Boyolali, Kab. } \\
\text { Demak, Kab. Grobogan, Kab. Jepara, Kab. Karanganyar, Kab. Kebumen, Kab. } \\
\text { Kendal, Kab. Klaten, Kota Magelang, Kota Semarang, Kab. Kudus, Kab. Magelang, } \\
\text { Kab. Pekalongan, Kab. Pemalang, Kab. Purworejo, Kab. Rembang, Kota Salatiga, } \\
\text { Kab. Semarang, Kab. Sragen, Kab. Sukoharjo, Kota Surakarta, Kab. Temanggung, } \\
\text { Kab. Wonogiri, Kab. Wonosobo, Kab. Bangkalan, Kab. Banyuwangi, Kota Batu, Kab. } \\
\text { Blitar, Kab. Bojonegoro, Kab. Bondowoso, Kab. Gresik, Kab. Jember, Kab. Jombang, } \\
\text { Kab. Kediri, Kota Blitar, Kota Kediri, Kota Madiun, Kota Malang, Kota Mojokerto, } \\
\text { Kota Pasuruan, Kota Probolinggo, Kab. Lamongan, Kab. Lumajang, Kab. Magetan, } \\
\text { Kab. Malang, Kab. Mojokerto, Kab. Nganjuk, Kab. Pacitan, Kab. Pamekasan, Kab. } \\
\text { Pasuruan, Kab. Ponorogo, Kab. Sampang, Kab. Sidoarjo, Kab. Situbondo, Kab. } \\
\text { Sumenep, Kota Surabaya, Kab. Trenggalek, Kab. Tuban, Kab. Tulungagung, Kab. } \\
\text { Bantul, Kab. Gunung Kidul, Kota Yogyakarta, Kab. Kulon Progo, Kab. Sleman }\end{array}$ & $13,07 \%$ \\
\hline
\end{tabular}

Hasil pengujian ketergantungan dan keragaman spasial berturut-turut disajikan pada Tabel 3 dan Tabel 4. Dari Tabel 3 diketahui bahwa LM SEM, LM SAR dan LM SAC signifikan, baik untuk model tanpa efek kelompok maupun untuk model dengan efek kelompok. Hal ini menunjukkan bahwa 
terdapat ketergantungan spasial, baik pada variabel dependen maupun pada error. Dengan demikian, model SAC adalah model yang cocok digunakan. Selanjutnya, dari Tabel 4 diketahui bahwa hasil uji BP tidak signifikan pada taraf nyata 5\%, baik untuk model tanpa efek kelompok maupun untuk model dengan efek kelompok. Dengan demikian disimpulkan bahwa data tidak mengandung keragaman spasial.

Tabel 3. Hasil pengujian ketergantungan spasial.

\begin{tabular}{lcccccc}
\hline & \multicolumn{3}{c}{ Model tanpa efek kelompok } & \multicolumn{3}{c}{ Model dengan efek kelompok } \\
\cline { 2 - 7 } & Statistik & Parameter & $p$-value & Statistik & Parameter & $p$-value \\
\hline LM SEM & 83,254 & 1 & $0,000^{* * *}$ & 7,578 & 1 & $0,006^{* *}$ \\
LM SAR & 74,450 & 1 & $0,000^{* * *}$ & 8,764 & 1 & $0,003^{* *}$ \\
LM SAC & 84,217 & 2 & $0,000^{* * *}$ & 10,137 & 2 & $0,006^{* *}$ \\
\hline
\end{tabular}

Keterangan: Signifikan pada taraf nyata 5\%*, 1\%**, 0,1\%***

Tabel 4. Hasil pengujian keragaman spasial.

\begin{tabular}{|c|c|c|c|}
\hline & $\mathrm{BP}$ & Derajat bebas & $p$-value \\
\hline Model tanpa efek kelompok & 0,869 & 2 & 0,648 \\
\hline Model dengan efek kelompok & 8,615 & 4 & 0,071 \\
\hline
\end{tabular}

Tabel 5 menyajikan hasil estimasi parameter untuk masing-masing model. Berdasarkan hasil tersebut, Model-3 adalah model terbaik dalam menjelaskan pengaruh kadar $\mathrm{NO}_{2}$ terhadap Indeks Kewaspadaan COVID-19. Hal ini diindikasikan oleh nilai $R_{a d j}^{2}$ yang paling besar serta nilai AIC yang paling kecil dibandingkan model lainnya. Model-3 mampu meningkatkan kinerja model dasar secara substansial. Selanjutnya, hasil pengujian menunjukkan bahwa kadar $\mathrm{NO}_{2}$ berpengaruh positif dan signifikan terhadap Indeks Kewaspadaan COVID-19, setelah efek kelompok dan efek spasial diperhitungkan. Semakin tinggi kadar $\mathrm{NO}_{2}$ yang mencerminkan semakin buruk kualitas udara, semakin tinggi pula kemungkinan transmisi COVID-19 di suatu wilayah. Sementara itu, variabel kepadatan penduduk tidak menunjukkan pengaruh yang signifikan pada semua model.

Tabel 5. Hasil estimasi parameter.

\begin{tabular}{|c|c|c|c|c|c|c|c|c|}
\hline & \multicolumn{2}{|c|}{ Model-0 } & \multicolumn{2}{|c|}{ Model-1 } & \multicolumn{2}{|c|}{ Model-2 } & \multicolumn{2}{|c|}{ Model-3 } \\
\hline & Estimasi & $p$-value & Estimasi & $p$-value & Estimasi & $p$-value & Estimasi & $p$-value \\
\hline \multirow[t]{2}{*}{ Konstanta } & 1,174 & $0,037 *$ & 0,994 & 0,308 & $-1,141$ & $0,028^{*}$ & $-0,800$ & 0,159 \\
\hline & $(0,56)$ & & $(0,97)$ & & $(0,51)$ & & $(0,57)$ & \\
\hline \multirow[t]{2}{*}{$\mathrm{NO}_{2}\left(10^{15} \mathrm{molekul} / \mathrm{cm}^{2}\right)$} & 0,273 & 0,108 & 0,232 & 0,202 & 0,437 & $0,000 * * *$ & 0,309 & $0,013^{*}$ \\
\hline & $(0,17)$ & & $(0,18)$ & & $(0,12)$ & & $(0,12)$ & \\
\hline \multirow[t]{2}{*}{ Kepadatan (000 pddk/km²) } & 0,023 & 0,721 & 0,058 & 0,237 & 0,029 & 0,478 & 0,033 & 0,387 \\
\hline & $(0,07)$ & & $(0,05)$ & & $(0,04)$ & & $(0,04)$ & \\
\hline \multirow[t]{2}{*}{ Dummy kelompok } & - & - & - & - & $-6,765$ & $0,000 * * *$ & $-6,699$ & $0,000 * * *$ \\
\hline & & & & & $(1,06)$ & & $(1,28)$ & \\
\hline \multirow[t]{2}{*}{ Dummy $^{*} \mathrm{NO}_{2}$} & - & - & - & - & 2,852 & $0,000 * * *$ & 2,735 & $0,000 * * *$ \\
\hline & & & & & $(0,30)$ & & $(0,39)$ & \\
\hline$\rho$ & - & - & 0,004 & - & - & - & 0,136 & - \\
\hline$\lambda$ & - & - & 0,650 & - & - & - & 0,285 & - \\
\hline$R^{2}$ & $6,42 \%$ & - & $43,71 \%$ & - & $64,99 \%$ & - & $68,19 \%$ & - \\
\hline$R_{a d j}^{2}$ & $4,81 \%$ & - & $42,24 \%$ & - & $63,76 \%$ & - & $66,79 \%$ & - \\
\hline AIC & 526,67 & - & 481,14 & - & 413,66 & - & 408,28 & - \\
\hline
\end{tabular}

Keterangan: Standard error dalam tanda (). Signifikan pada taraf nyata 5\%*, 1\%**, 0,1\%***

Tabel 6. Dampak langsung, dampak tak langsung dan dampak total berdasarkan Model-3.

\begin{tabular}{lrrrrrr}
\hline & \multicolumn{3}{c}{ Kelompok 1 } & & Kelompok 2 \\
\cline { 2 - 7 } & $\begin{array}{r}\text { Dampak } \\
\text { langsung }\end{array}$ & $\begin{array}{c}\text { Dampak tak } \\
\text { langsung }\end{array}$ & $\begin{array}{c}\text { Dampak } \\
\text { total }\end{array}$ & $\begin{array}{c}\text { Dampak } \\
\text { langsung }\end{array}$ & $\begin{array}{c}\text { Dampak tak } \\
\text { langsung }\end{array}$ & $\begin{array}{c}\text { Dampak } \\
\text { total }\end{array}$ \\
\hline Kadar $\mathrm{NO}_{2}\left(10^{15} \mathrm{molekul} / \mathrm{cm}^{2}\right)$ & 0,310 & 0,047 & 0,357 & 3,053 & 0,469 & 3,522 \\
Kepadatan $\left(000 \mathrm{pddk} / \mathrm{km}^{2}\right)$ & 0,033 & 0,005 & 0,038 & 0,033 & 0,005 & 0,038 \\
\hline
\end{tabular}


Besarnya dampak langsung, dampak tak langsung dan dampak total dari masing-masing variabel penjelas terhadap Indeks Kewaspadaan COVID-19 disajikan dalam Tabel 6. Dampak yang disajikan hanya berasal dari model terbaik, yaitu Model-3. Jika di suatu kabupaten/kota terjadi peningkatan kadar $\mathrm{NO}_{2}$ sebesar 1 kuadriliun molekul $/ \mathrm{cm}^{2}$, maka Indeks Kewaspadaan COVID-19 di kabupaten/kota tersebut akan meningkat sebesar 0,310 poin (jika kelompok 1) dan 3,053 poin (jika kelompok 2). Suatu kabupaten/kota akan mengalami peningkatan Indeks Kewaspadaan COVID-19 sebesar 0,047 poin (jika kelompok 1) dan 0,469 poin (jika kelompok 2) ketika di kabupaten/kota sekitarnya terjadi peningkatan kadar $\mathrm{NO}_{2}$ sebesar 1 kuadriliun molekul/ $\mathrm{cm}^{2}$. Dengan demikian, dampak total yang akan diterima oleh suatu kabupaten/kota akibat kenaikan kadar $\mathrm{NO}_{2}$ di seluruh wilayah adalah sebesar 0,357 poin (jika kelompok 1) dan 3,522 poin (jika kelompok 2).

\section{KESIMPULAN}

Hasil penelitian ini memperkuat temuan-temuan sebelumnya yang mengindikasikan bahwa terdapat hubungan yang erat antara polusi udara dan kejadian COVID-19. Namun, hasil ini perlu diinvestigasi lebih lanjut untuk mendapatkan gambaran yang utuh. Penelitian selanjutnya dapat memasukkan faktor lain seperti suhu dan kelembaban, prakondisi kesehatan dan mobilitas penduduk sebagai variabel kontrol. Jika kualitas udara memainkan peranan penting dalam kejadian COVID-19, maka hal ini memiliki implikasi penting untuk strategi pencegahan penyebaran COVID-19, khususnya pada daerah-daerah dengan tingkat pencemaran udara yang tinggi.

\section{DAFTAR PUSTAKA}

Aaron van Donkelaar, Randall V. Martin, Michael Brauer, N. Christina Hsu, Ralph A. Kahn, Robert C. Levy, Alexei Lyapustin, Andrew M. Sayer, and D. M. W. (2016). Global Estimates of Fine Particulate Matter using a Combined Geophysical. Environmental Science \& Technology, 50(7), 3762-3772. https://doi.org/10.1021/acs.est.5b05833

Andree, B. P. J. (2020). Incidence of COVID-19 and Connections with Air Pollution Exposure: Evidence from the Netherlands. 1(April). https://doi.org/10.1101/2020.04.27.20081562

Anselin, L., Bera, A. K., Florax, R., \& Yoon, M. J. (1996). Simple diagnostic tests for spatial dependence. Regional Science and Urban Economics, 26(1), 77-104. https://doi.org/10.1016/0166-0462(95)02111-6

Arbia, G. (2006). Spatial Econometrics: Statistical Foundations and Applications to Regional Convergence. In Spatial Econometrics. Springer.

Becchetti, L., Conzo, G., Conzo, P., \& Salustri, F. (2020). Understanding the Heterogeneity of Adverse COVID19 Outcomes: the Role of Poor Quality of Air and Lockdown Decisions. SSRN Electronic Journal, April. https://doi.org/10.2139/ssrn.3572548

Darlington, R. B., \& Hayes, A. F. (2017). Regression Analysis and Linear Models: Concepts, Application and Implementation. In The Guilford Press.

Development Bank, A. (2020). The Economic Impact of the COVID-19 Outbreak on Developing Asia. 9(128). https://doi.org/10.22617/BRF200096

Elhorst, J. (2014). Spatial Econometrics from Cross-Sectional Data to Spatial Panels. Springer. https://doi.org/10.1007/978-3-642-40340-8

Eskes, H., Van Geffen, J., Boersma, F., Eichmann, K.-U., Apituley, A., Pedergnana, M., Sneep, M., Veefkind, J. P., \& Loyola, D. (2019). Sentinel-5 precursor/TROPOMI Level 2 Product User Manual Nitrogendioxide. 147.

Informasi Terkini COVID-19 di Indonesia / KawalCOVID19. (n.d.). Retrieved August 7, 2020, from https://kawalcovid19.id/ 
LeSage, J. P. (2008). An introduction to spatial econometrics. Revue d'Economie Industrielle, 123(3), 19-44. https://doi.org/10.4000/rei.3887

Ogen, Y. (2020). Assessing nitrogen dioxide (NO2) levels as a contributing factor to coronavirus (COVID-19) fatality. Science of the Total Environment, 726, 138605. https://doi.org/10.1016/j.scitotenv.2020.138605 Wu, X., Nethery, R. C., Sabath, B. M., Braun, D., \& Dominici, F. (2020). Exposure to air pollution and COVID19 mortality in the United States: A nationwide cross-sectional study. MedRxiv, 2020.04.05.20054502. https://doi.org/10.1101/2020.04.05.20054502 